\section{Mega-Lecture theatres, disability education and human rights: A comparative study of four selected Ghanaian public universities}

\author{
Braimah, Awaisu Imurana $\bowtie$ \\ University of Education, Winneba, Ghana - West Africa (braawaisu@yahoo.com; baimurana@uew.edu.gh) \\ Ewusie Jabialu, Theresa \\ University of Education, Winneba, Ghana - West Africa (tejabialu@uew.edu.gh) \\ Mensah, Matilda Arko \\ University of Education, Winneba, Ghana - West Africa (mensah.matilda@yahoo.com)
}

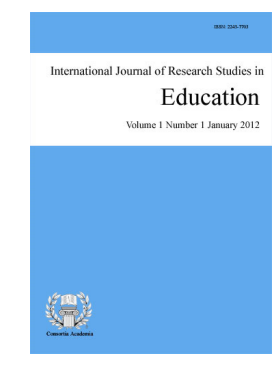

ISSN: 2243-7703 Online ISSN: 2243-7711

OPEN ACCESS

Received: 31 July $2017 \quad$ Revised: 26 August $2017 \quad$ Accepted: 30 September 2017

Available Online: 7 October 2017 DOI: 10.5861 /ijrse.2017.1886

\title{
Abstract
}

This paper interrogates the sociolegal nexus between mega infrastructure in tertiary institutions and accessibility of students with one form of disability or another for effective academic work. Disability is the physical impairment of the body either partial or permanent loss of limbs or sight which make locomotion and everyday life activities restrictive and oppressive. The physical impairment itself is a functional limitation for the individual but the individual also, has the potential to discover oneself to live 'normal' and independently with the necessary institutional structures and support of society. However, since the twilight of history, society has consciously or unconsciously stratified, segregated and excludes disabled persons via institutional, cultural and environmental mechanisms of denying the disabled of their basic human rights. Many tertiary institutions in Ghana have resorted to building gargantuan infrastructure in order to effectively maximize the use of limited land for future expansion and for aesthetic purposes. While the flourishing and expansion of these buildings are plausible, adequate access to this infrastructure has remained a serious challenge to students with disabilities. This phenomenon impact negatively on the academic performances of disabled students and a direct contravention to the freedom of movement enshrined in the Ghanaian constitution. We argue that discrimination, social exclusion and the various physical curtailment of movement of students with disabilities in tertiary institutions constitute a core human right violation.

Keywords: aesthetic; disability; discrimination; human rights; social exclusion 


\title{
Mega-Lecture theatres, disability education and human rights: A comparative study of four selected Ghanaian public universities
}

\section{Introduction}

The provision of education worldwide has become a human right issue. Many states have entrenched clauses in their various constitutions that see formal education as a right and not a privilege to all segments of society. By this, the state is not only to provide funding and access to education to citizens, but also ensure that, education delivery is devoid of discrimination of all forms on the basis of race, color, physical disability or ability, religion, cultural background, geographical location, ethnic, political and economic status among others. From this perspective, all modern states to some extent, assume responsibility for protecting the political, economic and social rights of citizens. This include among others, the protection of individual rights against hostile majorities and minorities (Encyclopaedia Britannica, 2012). Article 26 of the United Nations Universal Declaration of Human Rights states:

\begin{abstract}
Everyone has the right to education. [It] shall be free, at least in the elementary and fundamental stages. Elementary education shall be compulsory. Technical and professional education shall be made generally available and higher education shall be equally accessible to all on the basis of merit. Education shall be directed to the full development of the human personality and to the strengthening of respect for human rights and fundamental freedoms. It shall promote understanding, tolerance and friendship among all nations, racial or religious groups and shall further the activities of the United Nations for the maintenance of peace (as cited in Silverman \& Ruggles, 2007, p. 28).
\end{abstract}

Every society is made up of varied personalities (personality is narrowly construed in this paper to mean, the total summation of one's physical, psychological, moral and emotional characteristics). These personalities irrespective of their varied nature, are expected to be given equal treatment or opportunity in all sectors of the economy including educational. This basic right is universal to all by virtue of being a human. Article I of the United Nations Universal Declaration of Human Rights (1948) declares:

All human beings are born free and equal in dignity and rights. They are endowed with reason and conscience and should act towards one another in a spirit of brotherhood (p. 2)

Contrary to the mantra of equal rights and opportunities for all citizens by governments and civil society organizations, people and/or students with disabilities in the Ghanaian society to a large extent, are sequestered from the mainstream political, economic, education and civil rights activism as a result of the various forms of physical deformities or disabilities. As indicated by Ashurst and Venn (2014),

... the problem of school exclusion raises economic, political, social and historical issues which go to the heart of questions about an equitable and just society (Ashurst \& Venn, 2014, p. 1).

In the educational sector for instance, there appears equal treatment for all category of students in public tertiary institutions in Ghana weigh heavily against students with one form of disability or another. Mega structures are built in public tertiary institutions without due consideration to physical access of students with disabilities. As a consequence, having access to these mega infrastructural facilities (i.e., lecture halls, libraries, laboratories, transport and many others) by students with disabilities remain a daily nightmare. It cringes to see students with disabilities struggle to climb staircases with stack of papers and/or books hanging on their shoulders to access lecture halls and other facilities on the various campuses. In spite of Ghana's Disability Act 715 that enjoins all public institutions to create convenient access route(s) to people who are physically challenged, many institutions including the universities and other analogous tertiary institutions are yet to 
Mega-Lecture theatres, disability education and human rights: A comparative study of four selected universities

comply. Even structures currently under construction in many of the universities studied flagrantly ignore the physical access of students with disabilities they admit each year. According to the Disability Act (2006) on access to public places and public services states:

The owner or occupier of a place to which the public has access shall provide appropriate facilities that make the place accessible to and available for use by a person with disability (Article 6). Article 7 provides that, a person who provides service to the public shall put in place the necessary facilities that make the service available and accessible to a person with disability (Persons with Disability Act, 2006, p. 4).

In spite of these basic fundamental laws, it is mind-boggling why tertiary institutions and political leadership still do not pay heed to these provisions to protect the interest of students with disabilities on the various university campuses. Discussions on disability education that hinges on equality and human rights for students with disabilities importunate many people in the Ghanaian society. The significance of this study therefore seeks to transform or educate the public on the educational praxis, employ sociolegal approach to highlight the conditions of disability students in Ghanaian public institutions. The rationale is to trigger meaningful national discussion among policy makers, practitioners, the academia, the media and the general public on the need to find a workable solution to the plight of disability students in Ghanaian tertiary institutions. The study will also serve as a policy guide for future research on disability education. The study will suggest a refocus of some aspects of disability studies on the Ghanaian academic ladder to ensure equity for all citizens irrespective of their physical condition to ensure respect and dignity of individual rights for sustainable development.

\section{Methodology}

The study was designed to identify students with disabilities in public tertiary institutions Ghana. The aim and objective of this study was to obtain information on core services that are rendered to students with disabilities by management of tertiary institutions, to ensure physical access to lecture theatres and other essential services on the various campuses for effective teaching and learning. Hence, data and information for this study was collected from two main sources. The primary information was obtained from 100 students with one form of disability or another from four public tertiary institutions in Ghana (viz, University of Ghana; University of Cape Coast; University of Education, Winneba and University for Development Studies). Thus, the target population for this study was all students with one form of disability or another from the four selected public institutions. Twenty five (25) students with one form of disability or another were randomly sampled or recruited through convenience sample, from the pool of students with disabilities in each of the four public tertiary institutions studied. The objective was to recruit a more diverse population for the study. Hence, the total number of respondents' were100. Out of the number of participants, eighty (81) and 19 were males and females respectively. Approval for this study was given by institutional review board.

The main instruments employed for data collection were both questionnaire and face-to-face interaction depending on the option chosen by a respondent. The rationale or purpose for adopting the questionnaire was to give ample time to respondents to reflect adequately in order to provide adequate and accurate answers or response(s) to the questions posed. The primary information obtained was complemented with secondary data gleaned from monographs, books, journal articles, newspaper publications and magazines. The secondary data was critically subjected to scrutiny for accuracy and/or reliability.

\subsection{Data analysis}

Information for this study was organized into two groups. Questionnaire administration and focus group discussion. The latter was organized into five (5) groups. Each group was made up of five participants. The discussions took place in the individual university. The focus group discussion lasted for an average of 45 minutes. Permission was granted by respondents to record the proceedings of the discussion for later 
transcription. The former was mainly through distribution of questionnaires to individual participants according to their request. Participants were given three days (through mutual agreement) to reflect and provide accurate responses to the questions posed. The return rate of the questionnaire was overwhelmingly successful. Field notes were collected in lieu of body language and/or reaction of participants to complement information obtained and/or recorded for analytical purposes.

\subsection{Ethical consideration}

This study requires participants to discuss their various experiences vis-à-vis, disability and physical access to school facilities for effective academic work. The researcher recognizes the painful and emotional trauma participants may go through recounting these experiences. Consequently, research participants were pre-informed of the main purpose of the study. Accordingly, participants were given the option to either participate or withdraw from the study having been briefed on the purpose of the study. Research assistants were adequately trained in the line of questioning 'in order not to provoke the sensibilities and/or emotions of participants' (see Braimah, 2015, p.112). Research assistants approached participants' for interviews and collection of completed questionnaire on the various university campuses. Identity of participants and individual response(s) were anonymised to protect against exposure, victimization, vilification, labelling and name calling among others by their colleague students and society at large.

\section{Conceptualizing disability trajectory}

There is a plethora of empirical and compelling evidence to show that disabled students face a myriad of discriminations in tertiary institutions across nation-states. Yet, little attention is given to this phenomenon by society. The concept 'disability' has a chequered historical antecedence in social science discourse or research. Disability is a fluid terminology (some 'disability' researchers label the condition as 'abnormality', 'handicap', 'disorder', 'defect", 'special' etc. even though all the terms meant the same thing) and meant different thing to different people. These labels 'are highly contested: Their meanings are not clear, objective, and universal across time and space, and are contentious even for contemporaries in the same culture, profession and field' (Asch, 2001, p. 300). The series approach defines "disability" as a form of oppression ... in which disabled people are marginalized, restricted and experienced discrimination. The fundamental issue is not one of an individual's inabilities or limitation, but rather a hostile and unadaptive society" (Barton, 1999, p. ii).

According to the Americans with Disabilities Act (ADA) that provided civil right protections to people with disabilities defined disability as a 'physical or mental impairment that substantially limits one or more of the major life activities' (ADA, 2012). In the view of The Union of the Physically Impaired Against Segregation (UPIAS), 'disability is the disadvantage or restriction of activity caused by contemporary organization which takes no or little account of people who have physical impairments and thus excludes them from the mainstream of social activities' (UPIAS, 1976, p. 4). The various definitions of disability even though differ in wording; they essentially mean the same because of the following convergence. First, there is social exclusion of the disabled by the community and the wider society. Second, physical access to educational facilities and other institutions of the state impedes everyday movement of the disabled. Finally, that the restrictive activities of the disabled is socially constructed to create a parallel life style between the physically impaired and the rest of society. These categorization or stratification in society, makes it practically impossible for the disabled to develop their naturally given talents. Accordingly, disability studies over the years focused on the pursuit of equal rights (social, political and civil rights, economic and environmental rights) and emphasizing on physical access to public and private institutions and structures. This paper is a contribution to this debate. It argues for a sociolegal impairment and discusses two theoretical models (social model of disability and rights-based model) which may be used to create awareness of the educational praxies in the Ghanaian society for the purposes of adding to the growing call on government/policy makers and practitioners on the need to promote and protect the rights of students with disabilities in Ghana's tertiary institutions. 
Disability is narrowly construed in this study to mean, physical impairment of the body either partial or permanent loss of limbs or sight which make locomotion and everyday life activities restrictive and oppressive. From this perspective, the disabled people need the necessary support from the general public or society (i.e. state and indigenous institutions) to make life more meaningful and by ipso facto, assist them to discover their full potential(s) as humans. This definition is not so much concern about the mental impairment element of disability; but society's action or inaction toward people with disability and disabled students in particular. There are several dimensions or models of disability (e.g. medical, charity, rights based, social models and their like). We focused our attention thematically on the social and rights-based explanatory models to undergird this study. The rationale for choosing the two models was informed by its appropriateness in describing the social stratification and the exclusionary jeopardy of disabled students (or people) from physically accessing public facilities and its services to make everyday life activity somewhat bearable.

The Social Rights Model emerged as a direct response to the medical model of disability (the medical model perceives disability as the total deviation from the "normal" and therefore need to be cured or provide support services) which has been excessively criticized and rejected by disabled individuals and many other advocacy groups. As aptly argued by Imrie, the medical model of disability largely reflected the medical profession's view of the impaired body as an 'object of scientific interest, classification and medical intervention' (Imrie, 2004, p. 289).The rejection of the medical model was informed by its limitation on disability issues to doctor-patient relations where the latter need medical attention from the former as a panacea to the labyrinth of challenges or problems that confront disabled individuals in tertiary institutions (our focus). The social model of disability proposes an untenable separation between body and culture, impairment and disability (Hughes \& Paterson, 2006, p. 91).The social model view the plight of disability from the way society is organized. According to this model, the disabled in society are excluded from the day-to-day activities and/or participation in the society. This phenomenon is influenced by several misconceptions that include institutional, environmental and traditional/cultural and religious notions regarding disability in general. Environmentally, disabled persons are unable to physically access places such as educational facilities, hospitals, housing and places of convenience, transport, shops, tourist sites, support services, work/employment, access to register and vote in elections and their like. These oppressive social attitudes inhibit the disabled from not only developing their individual potentials, but continue to be dependent on the benevolence of a few individuals in society for survival. As clearly stated by the Union of the Physically Impaired Against Segregation,

In our view, it is society which disabled physically impaired people. Disability is something imposed on top of our impairments by the way we are unnecessarily isolated and excluded from full participation in society. Disabled people are therefore an oppressed group in society ... (UPIAS, 1976, p. 14).

The social model put premium on the physical inaccessibility or barriers placed in the way of disabled people by the general public and/or wider society - institutional and environmental obstacles. For instance, a disabled person in a wheelchair confronted by a flight of steps leading up to a public building, the challenge is not to the wheel chair user to do the impossible, but to society to make the building physically accessible by providing an alternative access route or entry (Bullock \& Trombley, 1999, p. 228). Hughes and Paterson argues that, the disability movement have successfully politicized social and physical space by drawing attention to the ways in which dominant, non-disabled values and practices constitute vast tracts of space as no-go areas (Hughes \& Paterson, 2006, p. 91). The social model, even though is embraced by the disabled and advocacy groups on equal rights for the disabled people in society, it was criticized for being dismissive of the injury or illness approach as advocated by the medical model - though injury or disease may be part of the wider picture of disability issues.

In spite of the criticism(s) of the social rights model, it is nevertheless, still relevant in explaining the plight of disability students' in public tertiary institutions under scrutiny. The difficulties in accessing lecture theatres by disabled students is as a result of the wider societal legacy. In other words, it will be a complete converse 
accident to blame the management of tertiary institutions for the present predicament of students with disabilities. It is a collective societal failure to create a congenial atmosphere for the disabled in society to develop and live independent life irrespective of their physical impairments. The participants of the study generally expressed their frustrations in accessing basic facilities such as lecture halls, hall of residences and libraries to mention but a few. The flight of steps that confront disabled students on daily basis from one lecture hall to another, and to hall of residences on the various university campuses effectively bogged down the academic input and output in terms of performance of disabled students. Support services put in place by management of the public universities were also limited vis-à-vis the population of students with disabilities. The laboratories meant to aid the studies of disabled students open and close at specific times. While the rest of non-disabled students can relax and later learn at midnight or early hours of the morning in the various residential libraries and/or lecture halls. The same cannot be said about students with disabilities. Every activity - attending lectures, working on assignments, albeit, the restrictive movement and physical access to education facilities - is cramped in a day for the disabled student. Since the twilight of history, there appear issues of disability has been treated with disdain and/or lack of respect by society. A reflection of social construction or exclusivity of the disabled people by the inadequacies of society is what is playing out in the various university campuses or tertiary institutions. To strengthen and address the inadequacies inherent in the social model, another model which is closely connected to the social model is the Rights-Based Model.

The Rights-Based Model put emphasizes on the attainment and respect of human rights of all persons including the disabled people in society - it focusses on the right and equal opportunities and participation in societal activity. Rights-based model advocates the pursuit of equal rights for disabled persons, focussing primarily on the questions of access and emphasizing the social, rather than the medical model of disability (Bullock \& Trombley, 1999, p. 228) Society in general, view disability as a personal tragedy and therefore exclude people with disabilities from participating fully in society's everyday activity. Society have thus failed to provide the needed conducive environment and opportunities for disabled individuals in tertiary institutions to feel part and parcel of society. As argued by Topliss and Gould,

Society may in fact, have expended too little in the way of resources and effort to adjust the environment, as much as many would wish, to meet the needs of disabled people, but the acceptance of an obligation to move in this direction has never been challenged ... (Topliss \& Gould, 1981, p. 142)

Human rights (or natural rights) are those which humankind is perceived to have by virtue of their humanity and not by virtue of human fiat or favor. Accordingly, the model calls for stringent reformation of society to ensure that the natural rights of persons with disabilities are upheld. Article 8 of the United Nations Convention on the Rights of Persons with Disabilities put responsibility on states 'to raise awareness throughout society ... and to foster respect for the rights and dignity of persons with disabilities' (UNCRPD, 2006, p. 7) The UNCRPD advocated political correctness - the principle of affirmative action to correct social stratification, segregation and exclusiveness of disabled persons in society. The purpose is to discourage labelling, albeit derogative to persons with disability to ensure inclusiveness in an integrated society. This will ensure that the existing society-induced barriers are eliminated as part of basic human rights for disabled persons in society. Accordingly, the model advocates integrated schooling or all-inclusive schooling - irrespective of one's physical, social and economic status. This presupposes that, under no circumstance should an individual be denied access to formal school setting by virtue of their physical appearance or compels to attend a special school by virtue of their physical condition against the will of the individual. In other words, every individual must be given the opportunity to choose to attend any school of their choice without visible or invisible restriction(s). The rights-based model perceives and recognizes the equality of all humans regardless of their physical, mental, social, economic and environmental circumstances. Hence, the model frowns upon segregation and discrimination against persons with disability both on and off academic. The rights based model, even though relevant and embraced by disabled persons and practitioners in the field of disability studies, it is more or less restrictive in its scope on human right and equality without giving specific prescriptions to make life more 

meaningful to disabled persons in society

\section{Land management, mega-infrastructure and the challenge of disability education}

The magnetic impulse and the coterie of tertiary institutions in Ghana to resort to building high rising infrastructure on their campuses, is mainly as a result of limited land economics. Many tertiary institutions have limited land available for future expansion. Management of these institutions therefore adopts 'innovative' and 'scientific' methods (high rising buildings) of utilizing effectively, the limited land available to take care of the present and future needs of the institutions to ensure sustainable development. The limited land conundrum in many tertiary institutions came about as a consequence of several years of government neglect (at least, to secure university lands through the building of fence wall) leading to land encroachment by influential and powerful politicians, accomplished businessmen and women, estate developers, the indiscriminate sale of land by chiefs among others. These powerful individuals in society usually prefer land closer to tertiary institutions where rental apartments or student hostels are built for business. The instrumental acquisition, encroachment and sale of land indiscriminately have left in its wake, limited land available for the universities in the face of the ever-growing interest of Ghanaian people in pursuing higher education. The desire by university management for further expansion of academic facilities is what is 'pushing' both government and management of public universities to resort to constructing high rising lecture halls, student hostels, laboratories, libraries, studios, and offices for lecturers - lecturers with disability struggle every working day to reach their offices while students with disabilities equally go through daily struggles to reach their lecturers for academic counselling or consultation. While this paper is not in any way against putting up high rising infrastructure on the various university campuses, the concern of this paper is the wanton neglect of government, management of public universities, architects and contractors alike to factor physical access to students with disabilities in the design of such high buildings.

In all these aesthetic architectural designs in tertiary institutions, the onus challenge is on the students with one form of disability or another. The high rising infrastructure on campuses affect students with disability in several ways: first, they are unable to cope with the demands of tertiary education owing to the inability to reach some facilities on time to do assigned project works or weekly assignments such as libraries, computers (this is a major challenge to blind students) and lecture halls. Second, the daily hassle students with disabilities always go through descending from one lecture theatre and commuting to another is a bane to effective academic work. Finally, teaching and learning materials are geared to the benefit of non-disabled students. Reading prospectus for the various courses or programs is not in brailed form. As a result, both partially and totally blind students are unable to read and digest the assigned reading materials by course instructors. This has negatively impacted on the academic performance of blind students in particular and students with disabilities as a whole.

\section{Disability education and human rights dichotomy}

The nature and structure of the Ghanaian educational system is problematic and also, discriminatory against disabled students. Students with disabilities are segregated from the non-disabled or the so called 'normal students' as a result of their physical impairment or medical condition. Hence, special education needs or schools are built to supposedly take care of their needs. Superficially, this policy may appear laudable. But in reality, the segregation is a well-orchestrated discrimination (owing to the physical impairment) against the will and the fundamental human rights of disabled individuals who seek education of their choice everywhere irrespective of their physical deformity with the so called 'normal' students. These students with disabilities are segregated and cramped in 'special schools' that creates the impression or label as educating students with 'abnormality'. If this is not the case, has there been any university or universities established specifically for the disabled since Ghana's independence? Since when do policy makers deemed it appropriate to offer inclusive education at the tertiary level for students with disabilities? These questions could be answered based on the negative and socially constructed labelling against disabled students or persons. The state or society from the twilight of humanity have 'condemned' disability to such labels as 'imbercile', 'abnormal', 'deformed', 'useless' and their 
like. Accordingly, society did not anticipate physically impaired individuals to rise above their immediate 'special schools' to seek higher education in the universities, technical universities or polytechnics and other analogous institutions. Hence, infrastructural development in tertiary institutions since the colonial epoch, have not put in place any deliberate policy to design or redesign institutional infrastructure to suit the needs of disabled persons. A refocus of the curriculum through inclusive or integrative schooling is an option or blueprint available to policy makers on education to consider in order to reduce the stigma associated with students in segregated schools.

\section{Prospects and perils of integrative schooling}

Inclusive education seeks to de-emphasise discrimination against students with disabilities not only in the academic environment, but society as a whole. The term 'inclusion' denotes a wider scope that includes disability. 'Inclusive education is about responding to diversity; it is about listening to unfamiliar voices, being open, empowering all members and about celebrating a "difference" in dignified ways. From this perspective, the goal is not to leave anyone out of school' (Barton, 1997, p. 233). Many other scholars such as Ryan and Paterna (1997) and Wilson (1999) are of the view that inclusion encompasses physical integration, placing students with disabilities in the same classroom as non-disabled peers; social integration, nurturing students relationships with peers and adults; and instructional integration, teaching students based on their needs and not a predetermined set of curricular standards (as cited in Friend \& Bursuck, 2002, p. 4). A school is inclusive to the extent that every student is able to identify and connect with his/her environment, culture, population and history (Dei, 1998, p. 208).

From this perspective, inclusive education or schooling in this paper refers to institutions that continuously admit and educate all manner of students irrespective of their physical appearance or disability into the mainstream educational setting. The paradigm shift in contemporary management of educational institutions is to integrate everyone in society's educational institutions in a quest to avoid discrimination and labelling. The benefits of inclusive or integrative schooling include among others: first, disability students are happy they are not only part of the natural school environment, but are also accepted as members of society. Special schools in spite of its good intentions, are to a large extent, creates some sort of social exclusion from the rest of society. Second, inclusive schooling helps to eliminate or reduce the problem of segregation and/or prejudice with respect to disability in general. It reinforces societal acceptance and the promotion of the 'equality' of humankind irrespective of one's physical appearance or impairment. Inclusive schooling from the formative to the senior school level prepares students with disability to cope with the strains or drudgery of tertiary education. Finally, inclusive schooling eliminates inferiority complex among students with disabilities - they see their class or school mates as co-equals working together to develop their individual talents. Inclusive schooling it is hypothesized will eventually eradicates or minimizes the negative stereotyping of students with disabilities by their school mates, and by extension, the wider community or society.

In spite of the importance of inclusive schooling, there is a plethora of teething problems or challenges envisaged or hypothesized if integrative school is implemented. The curriculum and the pedagogy of teacher training institutions need to be modified to take care of the demands of disability students. Teachers in mainstream schools must also be re-trained to cope and accept disability students as part of the integrative process. In other words, the training model for mainstream school teachers must concentrate on addressing diversity and achieving equity in the school environment and classroom settings. Infrastructure in the school and classroom setting call for upgrading to make learning beneficial to both disability students, slow learners and non-disabled students. Another concern is that, the teacher in an integrated school need adequate time (i.e., extension of lesson duration) and resources in the inclusive classroom setting to take care of the needs of all students. Furthermore, the teacher need more time in lesson notes preparation to encompass students with disability or special education needs. Again, the school and the teacher need to be able to deal with non-disabled students' sissy regarding students with disabilities to cope with the strains of academic work in the classroom. Finally and most importantly, teachers in an inclusive classroom setting may experience a sense of frustration 
owing to the stress of attending to the needs of both non-disabled and students with disabilities. However, these disadvantages of inclusive schooling could be surmounted if government and other stakeholders interested in disability education pool their resources, knowledge and skills together. Successive governments hiding behind the perennial coterie of lack of funds as a basis of perceiving disability as a personal tragedy is the bane of effective inclusive schooling in Ghana.

\section{Discussion of findings}

A study of this nature was conducted mainly adopting face-to-face group interviews and administration of questionnaire. From observation, the common motifs of participants before and during the conduct of the interviews were the idea of pent-up resentments, rejection, flippant and flummox treatment by society; and simmering frustrations being put on their way by government, management of tertiary institutions, non-disabled students and the wider society. Respondents' constructions of their identity were influenced by social construction of disability, their own experiences of living with impairment, and the 'attitudes and behaviors of those they interacted with' (Daruwalla, Chatterji, Shah More et al., 2013, p. 7). According to the participants, society expresses empathy of their disability but flutter round any concrete political correctness of social inclusion and the design of society's institutions to take care of their needs as disabled students. The plight of students with disabilities in Ghana's tertiary institutions as expressed by participants, have been categorized and organized along the following themes to make sense out of the data collected.

One of the key findings was access to relevant textbooks by disability students. According to the participants, many of the recommended reading prospectus of the various courses or subjects are not user friendly to blind students. These course prospectus are not in a brail form for easy reading. The lecturers' pedagogies in the various courses in the lecture theatres do not factor the educational needs of blind students in the lesson presentation or delivery. In the words of a blind student participant:

We are disadvantaged in every aspect. We the blind students have to rely on our course mates to read aloud to our hearing all assigned or recommended reading materials. How can we compete with colleagues who are not disabled in one way or another? This is affecting the quality of grades we get in each course of study. We are not bad or stupid academically. But we are simply part of an academic environment where we feel unwelcome and discriminated against.

The survey revealed that, many of the reading materials assigned by individual lecturers are not in brail form for the use of blind students. The various laboratories in the four public universities studied do not have the capacity in terms of human resource and equipment to assist students with disabilities in a manner that will make reading or learning much better. The net effect of this syndrome is that, many students in this category either abandon tertiary education altogether, or are counted among the worst performance through no fault of theirs. Those disability students, who usually abandon the pursuit of their program owing to frustration and inadequate support from parents and management of tertiary institutions to study, do not only become a burden on parents, but society in general. A few of them resort to begging for alms on the streets of Ghana for survival.

Another key finding that negatively affect students with disabilities on the various university campuses studied was limited time for studies. According to the participants, offices designated in the various universities to assist them in their study close 5:00pm every working day. As a result, the study period for students with disabilities are curtailed or brought to an end. While other students are able to access libraries and classroom facilities for evening and midnight studies, the same cannot be said with disabled students. Those with physical disabilities are unable to access with ease, books that are stocked in two or three storey building facilities. In the same vein, deaf and dumb students encounter difficulties in accessing relevant books and materials for effective academic work. The Liberians in the various public university libraries have no idea or clue to sign language to assist the deaf and dumb students. Colleague students who show the desire to help are equally not in a position to assist because; they do not understand the sign language. This, in one way or another, make university education 
Braimah, A. I., Ewusie Jabialu, T., \& Mensah, M. A.

for students with disabilities difficult and a nightmare to pursuing tertiary education.

In furtherance, access to lecture theatres, halls of residence, computer laboratories and other essentials such as water, toiletries and discrimination in boarding commercial vehicles on campus are key challenges to students with disabilities. Many of the lecture halls, halls of residence, amphitheatres and library facilities and even taxi cabs on campus, are not user friendly to students with disabilities. With the exception of University of Education, Winneba, where lifts are fitted to only the administrative block and the Faculty of Social Science Education (FSSE) block - the facility is comprised of a conglomeration of lecture halls - the rest of the universities studied are yet to fix lifts at major entry points such as mega or high rise lecture halls, libraries, laboratories and halls of residence to ameliorate the suffering of disabled students. Majority of the respondents (i.e. students with disabilities $85 \%$ ) expressed the following view as indicated below:

We attend lectures on time only at the benevolence of our course colleagues who are non-disabled. The execution of our weekly assigned project works are also dependent on our course mates for assistance in locating and photocopying relevant materials where necessary. There are times when these students are fatigued in assisting us to and from lecture halls, libraries and running secretariat errands for us. We are left to fend for ourselves especially before, during and end of semester examinations. These frustrations have sent some of our colleagues' home. In other words, they have abandoned tertiary education owing to some of these difficulties. We strongly suspect the lecturers don't favor us in any way when marking our examination scripts. They customarily, apply the same marking scheme across board. Our final grades are not usually good enough in comparison with the rest of our non-disabled colleague students.

Again, 21\% of the respondents were of the view that government must establish a university for disabled students. According to them, establishing such an institution will compel the political leadership in Ghana to provide adequate facilities or resources for effective teaching and learning. They remarked that,

The facilities currently in our various university campuses are inadequate to meet the demands of the ever increasing population of students with disabilities. These public universities were not established or envisaged that, students with disabilities will probably make it to the tertiary level as a result of societal neglect or exclusion over several decades. Unfortunately, the university community is as hostile as our communities where we live. Some of us thought the university environment at least will give us some respite from the everyday societal neglect. But it is a nightmare being in the university. Some of us will not succumb to truncate our quest to pursue tertiary education to meet our ambitions in life.

However, $76 \%$ of the respondents opposed to the advocacy or suggestion to establish a university for students with disabilities. They were of the view that, integrative schooling is an effective means to exorcise the negative perception of society against their impairment and development. They expect political leadership and management of public institutions in particular, to take practical steps to address teething problems that militate against their welfare on the various campuses. Adequate classroom facilities or resources to take care of the needs of students with disabilities are preferred to segregation. Participants were of the view that, pursuing tertiary education in an inclusive setting make them feel good and accepted.

Besides, inclusive schooling encourages competition between students with disabilities and non-disabled peers. As stated by the group:

we the students with disabilities always want to prove a point that, our physical disabilities or conditions will not make us succumb to societal neglect and discrimination by not pursuing higher education to the fullest. 


\section{Implications of disability studies in tertiary institutions}

There are several implications based on the study for students with disabilities and disability education in Ghana as a whole. The clutches hindering effective academic progress of students with disabilities in Ghanaian tertiary institutions have a direct psychological and mental torture for the individual and the wider society.

First, until government and management of tertiary institutions change the prevailing ethos and practices that will turn the situation where students with disabilities are cut off in their quest to obtain tertiary education as a right, a section of society (i.e., students with disabilities) is left behind to develop their own talents as a result of social as well as politico-environmental discrimination. There will be a steady national economic development in Ghana if educational facilities and teaching and learning materials are made physically accessible for all citizens irrespective of their physical appearances. Education that is devoid of discrimination will eventually have a positive impact on the economy since all and sundry it is envisaged, will contribute their quota in diverse ways for national development. There will be no meaningful or real development if issues on disability education are not adequately addressed in an inclusive manner by the powers that be in Ghana. Education delivery that is skewed to benefit non-disabled students to the detriment of students with disabilities will to some extent, stifle the national economic development effort of Ghana.

Another implication of neglecting the special education needs of students with disabilities in higher education increases school dropout rate. The implication is that, besides these dropouts being a burden on the immediate family, the wider society would in the long run; bear the consequences of not fixing the menace of students with disabilities. For instance, it is an embarrassing scene on daily basis to see these talented individuals with one form of disability or another, begging for alms for survival on the major streets in the capital city of Ghana (i.e., Accra). Some of them have resorted to social vices such as pick pocketing and other tricks on unsuspecting Ghanaians for survival. All attempts to get them out of the streets by city authorities have proved futile. This is a collective failure of society to recognize, provide critical resources for the education of disabled students and integrate people with disabilities in all spheres of societal life.

Again, the plight of students with disabilities in the Ghanaian society is viewed as non-problematic in public policy making. In spite of the increasingly sensitization against covert and overt discrimination and abuse of the fundamental human rights of people with disabilities (e.g. buildings or structures beyond the reach of students with disabilities) in tertiary institutions in Ghana, little attention is paid to resolve these concerns. Political authorities and the media seemed to mirror the reflection of society by perceiving the plight of the disabled students as not worthy of discussion and a personalized individual problem. From this perspective, Oliver (2006) argues that, the reason behind the inability of disabled people to participate fully and be heard by policy makers, practitioners and researchers stem directly from the physical and psychological limitations of the disabled person as a 'consequence of ... traumatic event, whether be it an accident or the onset of some progressive disease' (Oliver, 2006, p. 8).

Finally, students with disabilities feel dejected, rejected and ostracized by their family, community and the Ghanaian society as a whole. The inability of the state to provide adequate resources to lessen physical access to institutional infrastructure and other learning aid to the various categories of disability students (i.e., complete and partially blind students, hearing impairment and dumb students, physically challenged students etc.) in tertiary institutions, is a further pellucid and unshakable premonition of these students that, their physical presence in the various tertiary institutions has been ab initio declared persona non grata. As a consequence, there are increasingly, disability suffragettes (i.e., those who prefer to commit suicide or block public highway to demonstrate their frustration in accessing public infrastructure and transport) in the Ghanaian society. This has a potential to breach future national security if immediate steps are not taken not only to address the concerns of disabled students, but to make their stay and completion in school a priority. A social and public policy that excludes or ignores the demands for the provision of welfare for certain category of citizens (e.g. students with disabilities) is essentially a breach on the fundamental human rights and dignity of such individuals. 


\section{Conclusion and policy recommendations}

This paper is an attempt to trigger national argument or discourse on high rising infrastructure, disability education and human rights nexuses in Ghanaian tertiary institutions. The main instruments for data collection were questionnaires and focus group interviews. The target participants were students with disabilities in the studied Ghanaian public universities. The results distilled from this questionnaire showed that, the tertiary institutions studied, to a large extent, are not committed to making students with disabilities participate effectively and inclusively in the day-to-day academic gymnastics of the universities. This was due to managements' inability to secure financial wherewithal from government of Ghana and external funds to provide resources and/or facilities reminiscent of special education needs for students with disabilities. This study was therefore to brainstorm and find practical solution to the prevailing physical inaccessibility of public facilities by disability people in general and students with disabilities in tertiary institutions in particular. The plight of students with disabilities in the various public and private tertiary institutions in Ghana is a 'naked' reality of a complete societal neglect since the twilight of history. Individuals and institutions always show empathy to the students with disabilities or the disabled in society.

Accordingly, laws are enacted by the state superficially, to support the course and dignity of persons living with disability. The purpose of these laws was supposed to make or compel institutions to design facilities with the disabled individuals in mind. But such legislations are often flouted with impunity and without any sanction. Students with disabilities according to the survey results are not much interested with public sympathy or empathy on their condition, but against the feckless and sleazy treatment by society including tertiary institutions. Students with disabilities and by extension, all persons living with one form of disability or another are citizens with all the rights and privileges enshrined in the Ghanaian constitution. The physical and/or mental disability of an individual in society should not and must not be sequestered and treated as a second-rated citizen or discriminated against from any quarter. On the contrary, the state need to provide for their special educational needs to develop and become competitive (just as any other citizen or citizens) in the global environment. Disability is not incapacity insofar as society will create an enabling environment to develop their potentials in all sectors of the economy most especially in pursuit of tertiary education. For, tertiary education is one of the crucial avenues where individual talents are enhanced or developed for socio-economic development of a modern state. Accordingly, governments and other stakeholders in education must provide adequate resources and user friendly infrastructure to make the learning environment conducive for students with disabilities to unearth their talents for sustainable development. Governments must as well show enough commitment by prioritizing the provision of modern facilities such as computers for students with disabilities, hearing aid and other teaching and learning materials including transportation to facilitate integrated or inclusive tertiary institutions in Ghana.

\subsection{Policy recommendations}

This section recommends a refocus of educational policy of some aspects of disability studies. The study thematically focused on the reformation of the Ghanaian educational praxis - a combination of reflection and action directed at structures to be transformed, not ... least of which are schools, colleges and universities (Adams \& Sally, 2006, p. 1). Based on the discussions of the study, the following recommendations were offered to guide policy makers, practitioners and other stakeholders in disability education to improve upon educational facilities for the benefit of disabled students in Ghanaian tertiary institutions.

$>$ Policy makers must as a matter of urgency, consider inclusive or integrative schooling right from the basic school to the tertiary level. This will gradually eliminate discrimination and acceptance of disabled students as integral members of society.

$>$ To resolve education praxis throughout the country, government must take decisive wider policies to transform the existing institutional structures on the various university campuses - and indeed all 
educational institutions with mega infrastructural facilities - to make it less cumbersome for disabled students of varied nature to access. The Minister responsible for Social Welfare and Education must jointly hold an imbizo on disability education with the management of the various tertiary institutions with the view to addressing and resolving all bottlenecks that torpedo the academic prowess of students with disabilities in higher education.

Danagement or school administrators must ensure that the educational facilities on their campuses that are beyond the reach of disabled students are fitted with elevators or installation of lifts to transport both disabled and non-disabled students to all floors of such facilities - the University of Education, (Winneba campus) for instance, have already started fixing elevators to strategic structures (for example, the Administration block and the Faculty of Social Sciences block cum lecture halls) to ameliorate the plight or suffering of disabled students. Also, new facilities under construction must have designs with disabled students in mind - that must include not only the installation of lifts, but also, ramps and adaptations to halls of residences to enable disabled students live on campus with less stress (Adams \& Sally, 2006, p. 1).

D The current disability act 715 in operation must be made functional. In other words, institutions that fail to provide access route(s) to high rising infrastructure must be sanctioned according to Section 8 (this provide that persons who fail to adhere to Section 6, 7, and 8 commits an offence and is liable on summary conviction to a fine not exceeding fifty penalty units or a term of imprisonment not exceeding three months or both) of the Disability Act.

$>$ Time-table committees in the various universities should endeavor to give 30 minutes or more in between lectures. This will enable disabled students who are unable to afford cost of transportation to trek from one lecture theatre/room to another on time. It also will reduce emotions, tension and the anxiety of disabled students to reach lecture halls prior to the commencement of lectures. There must be a negotiated interstitial space between the school management, the staff responsible for the welfare of students with disabilities, and the disabled students to ensure the implementation of time-table intervals for the smooth and unimpeded academic work.

The media ought to assist by investigating and highlight the plight of students with disabilities in tertiary institutions. This will constantly put government and the Education Ministry on their toes to address challenges militating against the smooth pursuit of tertiary education by students with disabilities. This the media must consider as their core social responsibility to society.

Contributors: All authors contributed equally to the design of the study and actively participated in the preparation of the manuscript. Awaisu I. Braimah oversaw the qualitative analysis of this paper, and all three authors did the interviews. We again proofread the final version of the manuscript.

Statement of competing interests: The author(s) have no competing interests with respect to the research, authorship and publication of this article.

\section{References}

Adams, M., \& Sally, B. (2006). Introduction. In A. Mike \& S. Brown (Eds), Towards inclusive learning in higher education: Developing curricular for disabled students (pp. 1-3). London: Routledge.

Americans with Disabilities Act. (2012). Encyclopedia Britannica. Chicago: Britannica.

Asch, A. (2008). Disability, bioethics and human rights. In G. Albrecht, K. Seelman, \& M. Bury (Eds), The handbook of disability studies (pp. 300-314). Thousand Oaks, CA: Sage.

Ashurst, F., \& Venn, C. (2014). Inequality, poverty, education: The political economy of school exclusion. United 
Braimah, A. I., Ewusie Jabialu, T., \& Mensah, M. A.

Kingdom: Palgrave McMillan. https://doi.org/10.1057/9781137347015

Barton, L. (1997). Inclusive education: Romantic subversive or realistic. International Journal of Inclusive Education, 1(3), 231-242. https://doi.org/10.1080/1360311970010301

Barton, L. (1999). Disability, human rights and society. In A. Felicity \& L. Barton (Eds), Disability, human rights and education: Cross-cultural perspectives (pp. 1-6). Buckingham-Philadelphia: Open University Press.

Braimah, A. I. (2015). Academic terrorism and dropout rate in Ghanaian schools: A qualitative study of Northern Ghana. Journal of Educational Policy and Entrepreneurial Research, 2(10), 110-121.

Bullock, A., \& Trombley, S. (Eds.) (1999). The Norton dictionary of modern thought. New York: W.W. Norton and Company.

Daruwalla, N., Chakravarty, S., Chatterji, S., Shah More, N., Alcock, G., Hawkes, S., \& Osrin, D. (2013). Violence against women with disability in Mumbai: A qualitative Study. SAGE Open, 3, 1-9. https://doi.org/10.1177/2158244013499144

Dei, G. J. S. (2005). The challenge of inclusive schooling in Africa: A Ghanaian case study. Comparative Education, 41(3), 267-289. https://doi.org/10.1080/03050060500211641

Friend, M., \& Bursuck, W. D. (2002). Including students with special needs: A practical guide for classroom teacher (3rd ed.). USA, Boston: Allyn \& Bacon.

Hughes, B., \& Paterson, K. (2006). The social model of disability and the disappearing body: Towards a sociology of impairment. In L. Barton (Ed.), Overcoming disability barriers: 18 years of disability and society (pp. 91-107). London, Routledge: Taylor \& Francis Group.

Imrie, R. (2004). Demystifying disability: A review of the international classification of functioning. Disability and Health and Illness, 26(3), 287-305. https://doi.org/10.1111/j.1467-9566.2004.00391.x

Oliver, M. (2006). Social policy and disability: Some theoretical issues. In L. Barton (Ed.), Overcoming disability barriers: 18 years of disability and society (pp. 7-20). London, Routledge: Taylor and Francis Group.

Persons with Disability Act. (2006). Act 715. Ghana: Persons with Disability Act.

Political System. (2012). Encyclopedia Britannica. Chicago: Encyclopedia Britannica.

Ryan, S., \& Paterna, L. (1997). Junior high can be inclusive: Using natural supports and cooperative learning. Teaching Exceptional Children, 30(2), 36-41. https://doi.org/10.1177/004005999703000207

Silverman, H., \& Ruggles, D. F. (Eds.) (2007). Cultural heritage and human rights. New York: Springer Science + Business Media LLC. https://doi.org/10.1007/978-0-387-71313-7

Topliss, E., \& Gould, B. (1981). A charter for the disabled. Oxford: Blackwell and Robertson.

United Nations Convention on the Rights of Persons with Disabilities. (2006). Retrieved from http://www.un.org/esa/socdev/enable/rights/convtexte.htm

United Nations Universal Declaration of Human Rights. (1948). United Nations High Commissioner for Human Rights. Donegal/Pass Community Forum, June, 2006. Retrieved from http://www.caluniv.ac.in/global-mdia-journal/WINTER\%202010

Union of the Physically Impaired Against Segregation. (1976). Fundamental principles of disability. London: U.P.I.A.S.

Wilson, B. A. (1999). Inclusion: Empirical guidelines and unanswered question. Education and Training in Mental Retardation and Development Disabilities, 34, 119-133. 